Original article

\title{
Identification and physicochemical characterization of bacterial surface isolated from catering services in health establishment
}

\author{
Khadija Azelmad ${ }^{1}$, Fatima Hamadi ${ }^{1}$, Rachida Mimouni ${ }^{1}$, Hassan Latrache ${ }^{2}$, Khaddouj Amzil $^{1}$, Abdella El Boulani $^{1}$, \\ Aicha Aitalla ${ }^{1}$, Abdlhamid Elmousadik $^{1}$ \\ ${ }^{1}$ University Ibn Zohr, Agadir, Morocco \\ ${ }^{2}$ University Sultan Moulay Slimane, Beni-Mellal, Morocco
}

Received 07 May 2016, Accepted 25 May 2016

(C) 2016, Azelmad K., Hamadi F., Mimouni R., Latrache H., Amzil K., Boulani A.E., Aitalla A., Elmousadik A.

(C) 2016, Russian Open Medical Journal

Abstract: The initial interaction between microorganisms and substrata is mediated by physicochemical forces, which originate from the physicochemical surface properties of both interacting surfaces. In this context, we have determined the physicochemical proprieties (hydrophobicity, electron-donor and electron-acceptor) of 37 isolates belonging to three genres of bacteria: Pseudomonas spp., Staphylococcus spp. and some species of Enterobacteriaceae isolated from various surfaces of the equipment and materials used in health establishment catering services. The physicochemical properties of these isolates were determined by contact angles measurements via Sessile Drop Technique. The results revealed that $62 \%$ of all bacteria studied exhibit a hydrophilic character $\left(\Delta \mathrm{G}_{\text {iwi }}>0\right)$ and other strains have a hydrophobic character $\left(\Delta \mathrm{G}_{\mathrm{iwi}}<0\right)$. Also the results show that all strains have a high electron donor character (high $\mathrm{Y}^{-}$) (ranging from $22.8 \mathrm{~mJ} . \mathrm{m}^{-2}$ to 105.4 $\left.\mathrm{mJ} . \mathrm{m}^{-2}\right)$. Forty one percent of these strains have a high electron acceptor $(\gamma+)$ (ranging from $14.7 \mathrm{~mJ} . \mathrm{m}^{-2}$ to $\left.34.6 \mathrm{~mJ} . \mathrm{m}^{-2}\right)$ and the others express a low electron acceptor character.

Keywords: physicochemical properties, contact angles measurements, Pseudomonas spp., Staphylococcus spp., Enterobacteriaceae

Cite as Azelmad K, Hamadi F, Mimouni R, Latrache H, Amzil K, Boulani AE, Aitalla A, Elmousadik A. Identification and physicochemical characterization of bacterial surface isolated from catering services in health establishment. Russian Open Medical Journal 2016; 5: e0403.

Correspondence to Fatima Hamadi. E-mail: ha_fatima@yahoo.fr

\section{Introduction}

Given the hot climate of Morocco and the lifestyle change of the population, food is increasingly processed and therefore constitutes, once consumed, a risk to consumer health. Food is considered as the first cause of poisoning (22\%) [1]. During the period 1999-2008, the Poison Control Center and Pharmacovigilance Morocco (CAPM) have recorded 13638 cases of food poisoning related to: 11,677 statements provinces received by mail and 1961 statements collected by the Toxicological Information System. The frequency seems much lower than that of other countries such as France where the food poisoning affecting 40,000 people each year [2-3] and the United States where there are approximately 76 million cases of poisoning per year [4]. However, in developing countries, food-borne diarrheal diseases kill 1.9 million people annually [5].

In most countries, bacteria are the leading cause of Foodborne diseases (FBD) and seem to be the causative agents of more than two thirds of the recorded FBD outbreaks [6]. For example, among the predominant bacteria involved in these diseases, Staphylococcus aureus is a leading cause of gastroenteritis resulting from the consumption of contaminated food [6].

Biofilm is considered as part of the normal life cycle of bacteria in the environment [7], in which planktonic cells attach to solid surfaces, proliferating and accumulating in multilayer cell clusters embedded in an organic polymer matrix. This biofilm protects the bacterial community from environmental stresses, from the host immune system and from antibiotic attacks, as opposed to the situation for vulnerable and exposed planktonic cells [8]. This may contribute to the persistence of bacteria in food-processing environments, consequently increasing cross-contamination risks as well as subsequent economic losses due to recalls of contaminated food products. According to literature, food contamination by pathogenic bacteria could be the result of detachment of biofilm bacteria [9-14]. Several studies have reported that bacteria have the capacity to adhere to food contact surfaces such as polystyrene, polypropylene, stainless steel, glass, marble and granite, and also on food products [15-24]. This adhesion is the key step to biofilm formation, and is considered as the result of physico-chemicals interactions. These interactions depend on physicochemical properties of both substratum and cells surfaces. However, the change of these physicochemical properties may affect the biofilm formation, consequently, influence their persistence on food contact surfaces [25-31]. That's why the determination of the physicochemical properties such hydrophobicity and electron donor $\left(\gamma^{-}\right) /$electron acceptor $\left(\gamma^{+}\right)$ character, of the isolates is the key to understanding the bacterial 
adhesion and consequently biofilm formation. Several studies have demonstrated the importance of bacteria surface hydrophobicity in the adhesion process [32-36]. The role of electrondonor/electron acceptor in adhesion phenomenon has been also widely studied [23, 37-39].

The first objective of this study was to isolate bacteria from different materials and surfaces commonly used in the catering kitchens as: granite, polypropylene, porcelain and stainless steel. The second objective was to determine the physicochemical properties of these bacteria: hydrophobicity and electrondonor/acceptor character.

\section{Material and Methods}

The samplings were conducted from different surfaces of materials and equipment used in the catering kitchens in health establishment: stainless steel, porcelain, polypropylene and granite.

\section{Isolation and identification of bacteria}

The isolates sampling protocol was done according to standards and international standards (ISO 16266:2006, NF V 08014 and NF V08-050) with some additional assays. The surfaces samplings were scraped using a Swabs. The Swabs was suspended in peptone water in test tubes for the stock solution, after serial dilutions, we have seeded $0.1 \mathrm{~mL}$ of each dilution solution on selective media depending on the desired germ. The colony forming units (CFU) are discriminated and selected based on their morphology, then inoculated individually on Petri dishes containing specific culture medium to obtain mono-specific microbial cultures.

\section{Isolation and identification of Pseudomonas spp.}

Isolation and identification of Pseudomonas spp. were made using a procedure described in ISO 16266:2006 with some additional assays. We have seeded on selective media (Cetrimide agar plates) as already described, and we have incubated at $37^{\circ} \mathrm{C}$ for $48 \mathrm{~h}$. After $48 \mathrm{~h}$ we have selected the colonies that show a bluish/greenish or reddish brown pigmentation, or the colonies which were fluorescent when examined under $360 \pm 20 \mathrm{~nm}$ ultraviolet radiations. These colonies were subcultured on King $B$ plates at $37^{\circ} \mathrm{C}$ for $24 \mathrm{~h}$. The plates were examined under $360 \pm 20$ $\mathrm{nm}$ ultraviolet radiation. The presence of fluorescence during the five days of observation was considered a positive reaction. Additional assays: Gram staining, catalase activities, oxidase test, lipolytic activity, mobility test, antibiogramme. Also two growing temperatures, $4^{\circ} \mathrm{C}$ and $42^{\circ} \mathrm{C}$, were tested on nutrient agar for all the strains, following recommendations in complementary information in ISO 16266:2006. All strains also were subcultured on King A plates for five days. An observation of bluish/greenish pigmentation, caused by pyocyanin production, was considered presumptive evidence of the presence of $P$. aeruginosa.

Thereafter, two commercial biochemical characterization kits were used for the phenotypic identification of isolated strains: API $20 \mathrm{NE}$ (Biomérieux, France) and automated microbiology instruments reference BD-PHOENIX. This later technique was used for some strains only.

\section{Isolation and identification of Staphylococcus spp.}

Staphylococcus spp. were isolated and identified according to the standard procedure described in NF V 08-014 (1984) with some additional assays. We have seeded on selective media
(Chapman agar plates) and we have incubated at $37^{\circ} \mathrm{C}$ for $24 \mathrm{~h}$. Then the colonies undergo tests of Gram stain, catalase activity, oxidase tests, mobility tests, coagulase, ADNase and the API Staph (Biomerieux, France) also was used.

\section{Isolation and identification of Enterobacteriaceae}

Strains of Enterobacteriaceae were isolated and identified according to the procedure described in the NF V08-050 with some additional assays. We have seeded on selective media Violet Red Bile Lactose (VRBL) Agar and incubated at $44^{\circ} \mathrm{C}$ for 24 hours. Colonies were inoculated on the Eosin Methylene Blue Agar (EMB). Subsequently other tested identifications were made such as: Gram stain, catalase activity, oxidase tests, mobility tests, IMViC test and the API $20 \mathrm{E}$ (Biomerieux, France).

\section{Growth and cultures conditions}

The Strains identified were cultured in Luria Bertani medium containing the following components (per liter of distilled water): $10 \mathrm{~g}$ tryptone, $5 \mathrm{~g}$ yeast extract, $10 \mathrm{~g} \mathrm{NaCl}$ and $15 \mathrm{~g}$ agar. After incubation at $37^{\circ} \mathrm{C}$ for $24 \mathrm{~h}$, the cells were harvested by centrifugation for $15 \mathrm{~min}$ at $8400 \mathrm{xg}$ and were washed twice with, and resuspended in, $\mathrm{KNO}_{3}$ solution with ionic strength $(0.1 \mathrm{M})$.

Contact angle measurements and surface tension components

Contact angle measurements were performed using a goniometer (GB instruments, France) by the sessile drop method. One drop of a liquid was deposited onto dry bacteria surfaces. Contact angles were measured in triplicate with separately cultured bacteria. Three to six contact angle measurements were made on each substratum surface for all probe liquids including formamide (99\%), diiodométhane (99\%) and distilled water [40].

The method for measuring contact angles on bacterial layers has been described by Busscher et al. [41]. Briefly, a suspension of cells in $\mathrm{KNO}_{3}$ sterile solution was deposited on a cellulose acetate membrane filter $(0.45 \mu \mathrm{m})$ (Sartorius) by a first washing of the filter with $10 \mathrm{~mL}$ of distilled water for wetting, and then $10 \mathrm{~mL}$ of the cell suspension was added to obtain a thick lawn of cells after filtration using a negative pressure. The wet filters were placed carefully on a glass support with double-sided sticky tape and were allowed to air dry until so-called stable "plateau contact angles" could be measured. For each strain, three independently grown cultures were used, from which three filters of each were prepared and measured. Three to six contact angle measurements were made on each filter, for all liquids including water, formamide and diiodomethane.

The cell surface hydrophobicity was evaluated through contact angle measurements and using the approach of Van Oss and coworkers [40-42]. In this approach, the degree of hydrophobicity of a given material (i) is expressed as the free energy of interaction between two entities of that material when immersed in water $(w)$ $\Delta G_{\text {iwi }}$ : If the interaction between the two entities is stronger than the interaction of each entity with water $\Delta G_{i w i}<0$ the material is considered hydrophobic. Conversely, if $\Delta \mathrm{G}_{\mathrm{iwi}}>0$ the material is hydrophilic. $\Delta \mathrm{G}_{\text {iwi }}$ can be calculated through the surface tension components of the interacting entities, according to:

$$
\begin{aligned}
& \Delta G_{\text {iwi }}=2 \gamma_{\text {iw }}=-2\left[\left(\gamma^{\mathrm{LW}}\right)^{1 / 2}-\left(\left(\gamma_{\mathrm{w}}{ }^{\mathrm{LW}}\right)^{1 / 2}\right)^{2}+2\left(\gamma^{+}{ }^{+} \mathrm{ji}^{-}\right)^{1 / 2}+\left(\gamma_{\mathrm{w}}{ }^{+} \gamma_{\mathrm{w}}{ }^{-}\right)^{1 / 2}-\right. \\
& \left.\left(\gamma_{i}^{+} \gamma_{w^{-}}\right)^{1 / 2}-\left(\gamma_{w}{ }^{+} \gamma_{i}^{-}\right)^{1 / 2}\right] \text {. }
\end{aligned}
$$




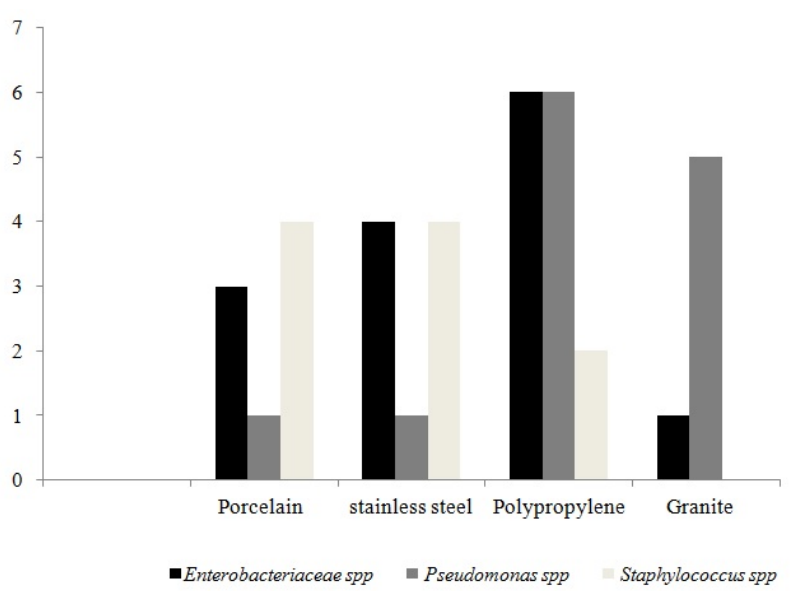

Figure 1. Number of strains samples isolated from different surfaces catering services.

The Lifshitz-Van der Waals $\left(\gamma^{\mathrm{LW}}\right)$, electron donor $(\gamma)$ and electron acceptor $\left(\gamma^{+}\right)$components of the surface tension of bacteria and for the solid substrates were estimated from the approach proposed by Van Oss et al. [39]. In this approach the contact angles $(\theta)$ can be expressed as:

$$
\cos \theta=-1+2\left(\gamma_{S}{ }^{L W} \gamma_{L}{ }^{L W}\right)^{1 / 2} / \nu_{L}+2\left(\gamma_{S}{ }^{+} \gamma_{L}\right)^{1 / 2} / \nu_{L}+2\left(\gamma_{S} \gamma_{L}+\right)^{1 / 2} / \nu_{L}
$$

$\theta$ is measured by contact angle. (S) and (L) denote solid surface and liquid phases respectively.

Lewis acid-base surface tension component is defined by:

$$
\gamma_{s}^{A B}=2\left(\gamma_{s}^{-} \gamma_{s}^{+}\right)^{1 / 2}
$$

\section{Results}

\section{Bacterial identification}

Thirty-seven strains were isolated from a catering in a health establishment during this study. 13 of the 37 strains were identified as Pseudomonas spp. In which 9 strains were identified as $P$. aeruginosa by the following assays, which are included in the ISO 16266: 2006. The results were confirmed by API 20 NE system that identified 9 of the 13 strains as $P$. aeruginosa too, with a percentage of identification between $83.8 \%$ and $99.9 \%$ (Table 1 ).

Also, 10 of 37 strains were identified as Staphylococcus spp. according to NF V 08-014: 1984 and one strain was identified as S. aureus. These results were confirmed by API Staph system with a percentage of identification between $57.2 \%$ and $99.9 \%$ (Table 2).

Finally 14 strains were identified as species of Enterobacteriaceae by NF V08-015and API 20 E system with a percentage of identification between $43.0 \%$ and $99.1 \%$ (Table 3 ).

The results reported in Figure 1, show the number of bacteria isolated from different surfaces: stainless steel, porcelain, polypropylene and granite. These results show that the bacteria of the species of Enterobacteriaceae and Pseudomonas are more abundant on polypropylene and granite surfaces and those of Staphylococcus are more abundant on the porcelain and stainless steel surfaces. Moreover, if we take into account all individual species, we notice that the polypropylene is the most colonized by these bacteria in the order of (38\%), followed by stainless steel $(24 \%)$ and porcelain $(22 \%)$ and finally granite $(16 \%)$.
Typically the polypropylene is the substratum that builds the cutting board used in almost every kitchen that will be collective or domestic. These cutting boards are a synthetic polymer which exhibits an important roughness which makes it the most susceptive material to be colonized by bacteria. On the other hand, the difference in level of physicochemical properties between substrates could explain the high percentage of attached bacteria on polypropylene.

Evaluation of bacterial surface hydrophobicity and electron donor/acceptor character

The surface hydrophobicity $\Delta \mathrm{G}_{\text {iwi }}$ and the electron donor $\left(\gamma^{+}\right) /$ electron acceptor $(\gamma)$ character of all bacteria were analyzed and listed in: Table 4 for Pseudomonas spp., Table 5 for Staphylococcus spp. and Table 6 for Enterobacteriaceae.

The results presented in Table 4, reported that $46 \%$ of Pseudomonas spp.exhibit a hydrophobic character $\left(\Delta \mathrm{G}_{\text {iwi }}<0\right)$, and $56 \%$ have a hydrophilic character $\left(\Delta \mathrm{G}_{\text {iwi }}>0\right)$ with a marked hydropholicity for $P$. aeruginosa (P15). Also, the results show that all strains have a high electron donor character and $P$. aeruginosa (P15) expressed the high electron donor $\left(\gamma^{-}=105.4 \mathrm{~mJ} \cdot \mathrm{m}^{-2}\right)$. Compared to literature $[21,32]$, the results show that the cells surfaces for studied bacteria expressed a high electron acceptor character. Some Pseudomonas strains have a high electron acceptor character for example (P4, P5 and P12), and the other strains have a medium and low electron acceptor character.

The Table 5 shows that $40 \%$ of Staphylococcus spp. exhibit a hydrophobic character $\left(\Delta \mathrm{G}_{\mathrm{iwi}}<0\right)$, and the others were hydrophilic $\left(\Delta G_{\text {iwi }}>0\right)$. Moreover, all strains have a high electron donor character (high $\gamma$ ) and the maximum character was noted for Staphylococcus spp. (S6). $\left(\gamma^{-}=59.2 \mathrm{~mJ} . \mathrm{m}^{-2}\right)$. For electron acceptor character, similar results of Pseudomonas spp. were observed for Staphylococcus spp. (S8, S9, S17 and S18).

According to the (Table 6), $29 \%$ of Enterobacteriaceae werehydrophobic and $71 \%$ were hydrophilic. We observed that all the strains have a high electron donor character (high $\gamma^{-}$) and the strain E11 have a marked character $\left(\gamma^{-}=63.1 \mathrm{~mJ} . \mathrm{m}^{-2}\right)$. As already noted, the electron acceptor character is also marked for Enterobacteriaceae. Enterobacter agglomerans (E4) and Enterobacte rcloace (E10) have important values of the electron acceptor character.

\section{Discussion}

If we take account of the origin of bacteria we see that the isolated bacterial cells from porcelain before and after cleaning and disinfecting operations were all hydrophilic $\left(\Delta \mathrm{G}_{\text {iwi }}>0\right)$ but a single strain of Staphylococcus spp. (S8) was hydrophobic $\left(\Delta G_{\text {iwi }}<0\right)$. In contrast, the other bacteria isolated from stainless steel, polypropylene and granite were hydrophilic and hydrophobic. In the light of the obtained results, we can see also that the level of hydrophobicity and electron donor/acceptor character change between same species. Moreover, no clear relation was obtained between origin and hydrophobicity or electron donor/acceptor character of all strains. This fact is corroborated by the results presented by Teixeira et al. [35] when they have determined the hydrophobicity of 10 strains of $P$. aeruginosa, based on contact angle measurements. They observed that each individual strain used had different degrees of hydrophobicity between genera of bacteria and strains of the same species. The same observations have been noted by Van der Mei et al. [32] when studying 142 isolates of various species 
among them P. aeruginosa, E. coli, Staphylococcus spp., Enterococci and Streptococci and they reported that no clear generalizations were noted concerning the physico-chemical surface properties between strains. Also the same results were found by Flint et al. [43] when determining the hydrophobicity of 12 strains of Streptococci spp. and they observed that each individual of thermophilic Streptococci spp. had different degrees of hydrophobicity.

\section{Conclusion}

In this work, we have isolated, identified and determined the physicochemical properties of bacteria isolated from different materials commonly used in the catering kitchens in establishment health. These results emphasizes that the level of hydrophobicity and electron donor/acceptor character changes between same species. It was the first time that the electron acceptor character is marked for most of the studied bacteria. Also we have noted that the polypropylene was the most colonized material compared to the other substratum.

\section{Conflict of interest: none declared.}

\section{References}

1. Ouammi L, Rhalem N, Aghandous R, Semllali I, Badri M, Jalal G, et al. Profil épidémiologique des intoxications au Maroc de 1980 à 2007. Toxicologie Maroc 2009; (1): 8-13.

2. Noyer D. Crises alimentaires. Chambre Régionale d'Agriculture de Normandie, 2002.

3. Delmas G, Gallay A, Espie E, Haeghebaert S, Pihier N, Weill FX, et al. Les toxi-infections alimentaires collectives en France entre 1996 et 2005. Bulletin Epidémiologique Hebdomadaire 2006; 51-52: 418-422.

4. Hadrya F, benlarabi S, Benali D, Hami H, Soulaymani A, SoulaymaniBencheikh R. Cartographie et analyse des données relatives aux intoxications liées aux aliments au maroc. Séminaire Inetrnational VSST Palais des congrès d'Ajaccio Corse de sud France, 2012.

5. Andargie G, Kassu A, Moges F, Tiruneh M, Huruy K. Prevalence of bacteria and intestinal parasites among food-handlers in Gondar Town, Northwest Ethiopia. J Health Popul Nutr 2008; 26(4): 451-455. PMID: 19069624

6. Vázquez-Sáncheza D, Olivier $H$, Askild $H$. Impact of food-related environmental factors on the adherence and biofilm formation of natural Staphylococcus aureus isolates. Curr Microbiol 2013; 66: 110121. PMID: 23064971. DOI: 10.1007/s00284-012-0247-8.

7. Otto M. Staphylococcal biofilms. Curr Top Microbiol Immun 2008; 322: 207-228. PMID: 18453278.

8. Costerton JW, Cheng KJ, Geesey GG, Ladd TI, Nickel JC, Dasgupta M, Marrie TJ. Bacterial biofilms in nature and disease. Annu Rev Microbiol 1987; 41: 435-464. DOI: 10.1146/annurev.mi.41.100187.002251.

9. Holah JT, Betts RP, Thorpe RH. The use of epifluorescent microscopy to determine surface hygiene. International Biodeterioration 1989; 25 : 147-153. DOI: 10.1016/0265-3036(89)90040-7.

10. Holah JT, Kearney LR. Introduction to biofilms in the food industry. In: Biofilms: Science and Technology. Melo, L.F., Bott, T.R., Fletcher, M. and Capdeville, B. Dordrecht eds. Kluwer Academic Publishers, 1992: 35-44.

11. Mattila-Sandholm T, Wirtanen G. Biofilm formation in the food industry: a review. Food Reviews International 1992; 8: 573-603. DOI: 10.1080/87559129209540953.

12. Carpentier B, Cerf O. Biofilms and their consequences with particular reference to hygiene in the food industry. J Appl Bacteriol 1993; 75: 499-511. PMID: 8294303. DOI: 10.1111/j.1365-2672.1993.tb01587.x.
13. Zottola EA, Sasahara KC. Microbial biofilms in the food processing industry - should they be a concern. Int J Food Microbiol 1994; 23: 125-148. DOI: 10.1016/0168-1605(94) 90047-7.

14. Costerton JW, Geesey GG, Cheng KJ. How bacteria stick. Sci Am 1978; 238: 86-95. DOI: 10.1038/scientificamerican0178-86.

15. Devita MD, Wadhera RK, Theis ML, Ingham SC. Assessing the potential of Streptococcus pyogenes and Staphylococcus aureus transfer to foods and customers via a survey of hands, hand-contact surfaces and food-contact surfaces at foodservice facilities. J Food Serv 2007; 18: 76-79. DOI: 10.1111/j.1745-4506.2007.00049x.

16. Herrera FC, Santos JA, Otero A, García-López ML. Occurrence of foodborne pathogenic bacteria in retail prepackaged portions of marine fish in Spain. J Appl Microbiol 2006; 100: 527-536. DOI: 10.1111/j.1365-2672.2005.02848.x.

17. Sattar SA, Springthorpe S, Mani S, Gallant M, Nair RC, Scott E, Kain J. Transfer of bacteria from fabrics to hands and other fabrics: development and application of a quantitative method using Staphylococcus aureus as a model. J Appl Microbiol 2001; 90: 962-970. PMID: 11412326. DOI: 10.1046/j.1365-2672.2001.01347.x.

18. Simon SS, Sanjeev S. Prevalence of enterotoxigenic Staphylococcus aureus in fishery products and fish-processing factory workers. Food Control 2007; 18: 1565-1568. DOI: 10.1016/j.foodcont.2006.12.007.

19. Teixeira P, Lima J, Azeredo J, Oliveira R. Adhesion of Listeria monocytogenesto materials commonly found in domestic kitchens. Int J Food Sci Technol 2008; 43: 1239-1244. DOI: 10.1111/j.13652621.2007.01598.x.

20. Silva S, Teixeira P, Oliveira R, Azeredo J. Adhesion to and viability of Listeria monocytogeneson food contact surfaces. J Food Protection 2008; 71: 1379-1385. PMID: 18680936.

21. Careli RT, Andrade NJ, Soares NF. The adherence of Pseudomonas fluorescens to marble, granite, synthetic polymers, and stainless steel. Ciência Tecnologia Alimentos 2009; 29: 171-176. DOI: 10.1590/S010120612012005000008.

22. Hamadi F, Latrache $H$,Zekraoui M. Effect of $\mathrm{pH}$ on surface energy of glass and teflon and theoretical prediction of Staphylococcus aureus adhesion. Mater Sci Eng 2009; 29: 1302-1305. DOI: 10.1016/j.msec.2008.10.023.

23. Hamadi F, Asserne F, Elabed S. Adhesion of Staphylococcus aureus on stainless steel treated with three types of milk. Food Control 2014; 38: 104-108. DOI: 10.1016/j.foodcont.2013.10.006.

24. Akpolat NO, Elçi S, Atmaca S, Akbayin H, Gül K. The effects of magnesium, calcium and EDTA on slime production by Staphylococcus epidermidis strains. Folia Microbiol 2003; 48: 649-653. DOI: 10.1007/BF02993473.

25. Moretro T, Hermansen L, Holck AL, Sidhu MS, Rudi K, Langsrud S. Biofilm formation and the presence of the intercellular adhesion locus ica among staphylococci from food and food-processing environments. Appl Environ Microb 2003; 9: 5648-5655. DOI: 10.1128/AEM.69.9.5648-5655.2003.

26. Pagedar A, Singh J, Batish VK. Surface hydrophobicity, nutritional contents affect Staphylococcus aureus biofilms and temperature influences its survival in preformed biofilms. J Basic Microbiol 2010; 50: 98-106. DOI: 10.1002/jobm.201000034.

27. Planchon S, Gaillard-Martinie B, Dordet-Frisoni E, Bellon-Fontaine MN, Leroy S, Labadie J, et al. Formation of biofilm by Staphylococcus xylosus. Int J Food Microbiol 2006; 109: 88-96. PMID: 16503066. DOI: 10.1016/j.jjfoodmicro.2006.01.016.

28. Poulsen LV. Microbial biofilm in food-processing. LWT-Food Sci Technol 1999; 32: 321-326. DOI: 10.1006/fstl.1999.0561.

29. Rode TM, Langsrud S, Holck A, Moretro T. Different patterns of biofilm formation in Staphylococcus aureus under food-related stress conditions. Int J Food Microbiol 2007; 116: 372-383. DOI: 10.1016/j.ijfoodmicro.2007.02.017. 
30. Xu H, Zou Y, Lee HY, Ahn J. Effect of $\mathrm{NaCl}$ on the biofilm formation by foodborne pathogens. J Food Sci 2010; 75: 580-585. DOI: 10.1111/j.1750-3841.2010.01865.x.

31. Van der Mei HC, Brokke P, Dankert J, Jan FJ, Rouxhet PG, Busscher HJ. Physicochemical surface properties of nonencapsulated and encapsulated coagulase negative staphylococci. Appl Environ Microbiol 1989; 55: 2806-2814. PMID: 2624461.

32. Teixeira $P$, Oliveira $R$. Influence of surface characteristics on the adhesion of alcaligenes denitrificans to polymeric substrates. J Adhesion Sci Technol 1999; 13: 1287-1294. DOI: 10.1163/156856199X00190.

33. Pereira MA, Alves MM, Azeredo J, Mota M, Oliveira R. Influence of physico-chemical properties of porous microcarriers on the adhesion of an anaerobic consortium. J Ind Microbiol Biotechnol 2000; 24: 181186. DOI: 10.1038/sj.jim.2900799.

34. Teixeira P, Zulmira L, Azeredo J. Physico-chemical surface characterization of a bacterial population isolated from a milking machine. Food Microbiol 2005; 22: 247-251. DOI: 10.1016/j.fm.2004.03.010.

35. Hamadi $\mathrm{F}$, Latrache $\mathrm{H}$. Comparison of contact angle measurement and microbial adhesion to solvents for assaying electron donor-electron acceptor (acid-base) properties of bacterial surface. Colloids Surf $B$ 2008; 65: 134-139. DOI: 10.1016/j.colsurfb.2008.03.010.

36. Van Oss CJ, Visser H. Protein Interactions. Weinheim, Germany, 1992.

37. Boulangé-Petermann L, Baroux B, Bellon-Fontaine MN. The influence of metallic surface wettability on bacterial adhesion. J Adhes Sci Technol 1993; 7(3): 221-230. DOI: 10.1163/156856193X00673.

38. Van Oss CJ. Acid-base interfacial interactions in aqueous media. Colloid Surface 1993; 78: 1-49. DOI: 10.1016/0927-7757(93)80308-2.

39. Van Oss CJ, Chaudhury MK, Good RJ. Interfacial Lifshitz-van der Waals and polar interactions in macroscopic systems. Chem Rev 1988; 88: 927-941. DOI: 10.1021/cr00088a006.

40. Busscher HJ, Weerkamp AH, van der Mei HC, van Pelt AW, de Jong HP, Arends J. Measurement of the surface free energy of bacterial cell surfaces and its relevance for Adhesion. Appl Environ Microbiol 1984; 48: 980-983. PMID: 6508312.

41. Van Oss CJ. Forces interfaciales en milieu aqueux. Paris, Masson, 1996.

42. Flint SH, Brooks JD, Bremer PJ. The influence of cell surface properties of thermophilic streptococci on attachment to stainless steel. J Appl Microbiol 1997; 83: 508-517. PMID: 9351231. DOI: 10.1046/j.13652672.1997.00264.x.

\section{Authors:}

Khadija Azelmad - PhD student, Laboratory of Microbial Biotechnology and Plant Protection, Faculty of Sciences, University Ibn Zohr, Agadir, Morocco.

Fatima Hamadi - Professor, Laboratory of Microbial Biotechnology and Plant Protection, Faculty of Sciences, University Ibn Zohr, Agadir, Morocco. Rachida Mimouni - Professor, Laboratory of Microbial Biotechnology and Plant Protection, Faculty of Sciences, University Ibn Zohr, Agadir, Morocco. Hassan Latrache - Professor, Laboratory of Bioprocess and Biointerfaces, Faculty of Science and Techniques, University Sultan Moulay Slimane, BeniMellal, Morocco.

Khaddouj Amzil - PhD student, Laboratory of Microbial Biotechnology and Plant Protection, Faculty of Sciences, University Ibn Zohr, Agadir, Morocco. Abdella El Boulani - PhD student, Laboratory of Microbial Biotechnology and Plant Protection, Faculty of Sciences, University Ibn Zohr, Agadir, Morocco.

Aicha Aitalla - Professor, Laboratory of Microbial Biotechnology and Plant Protection, Faculty of Sciences, University Ibn Zohr, Agadir, Morocco.

Abdlhamid Elmousadik - Professor, Laboratory of Biotechnology \& Valorization of Natural Resources, Faculty of Science, University Ibn Zohr, Agadir, Morocco. 
Table 1. Various biochemical tests for the identification of Pseudomonas spp. strains

\begin{tabular}{|c|c|c|c|c|c|c|c|c|c|c|c|c|c|c|c|}
\hline \multirow[t]{2}{*}{ Code of strains } & \multicolumn{2}{|c|}{$\begin{array}{c}\text { Automated microbiology } \\
\text { instruments Reference BD- } \\
\text { PHOENIX }\end{array}$} & \multicolumn{13}{|c|}{ Biochemical tests } \\
\hline & Identification & $\begin{array}{c}\text { Confidence } \\
\text { value }\end{array}$ & Origin & $\begin{array}{l}\text { Gram } \\
\text { stain }\end{array}$ & $\begin{array}{c}\text { test } \\
\text { Oxidase }\end{array}$ & $\begin{array}{c}\text { Catalase } \\
\text { tests }\end{array}$ & $\begin{array}{c}\text { Cetrimide } \\
\text { agar }\end{array}$ & $\begin{array}{c}\text { King } \\
B\end{array}$ & $\begin{array}{c}\text { King } \\
\text { A }\end{array}$ & $\begin{array}{l}\text { Lipase: ; } \\
\text { Tween } 80 \\
\text { hydrolysis } \\
\text { test }\end{array}$ & $\begin{array}{l}\text { Growth } \\
\text { at } 4{ }^{\circ} \mathrm{C}\end{array}$ & $\begin{array}{c}\text { Growth at } \\
42^{\circ} \mathrm{C}\end{array}$ & $\begin{array}{c}\text { Tests } \\
\text { mobility }\end{array}$ & $\begin{array}{l}\text { levan } \\
\text { test }\end{array}$ & Profile API 20 NE \\
\hline $\begin{array}{l}\text { P. aeruginosa } \\
\text { NCTC } 10332 \mathrm{~T}\end{array}$ & & & & & & & & + & + & $* *$ & - & + & + & - & $\begin{array}{l}\text { Witness (P. Aeruginosa } \\
\text { ATCC 27853) }\end{array}$ \\
\hline P1 & ** & & Granite before C/D & bacillus - & + & + & + & + & - & - & - & + & + & + & P. stutzeri $83.8 \%$ \\
\hline P3* & P. aeruginosa & $99 \%$ & Granite before C/D & bacillus - & + & + & + & + & + & + & - & + & + & ++ & P. aeruginosa $98.5 \%$ \\
\hline P4 & ** & & Granite before $C / D$ & bacillus - & + & - & + & - & - & - & - & - & + & + & P. aureofaciens $95.6 \%$ \\
\hline P5* & $* *$ & & Granite before $C / D$ & bacillus - & + & + & + & + & + & + & - & + & + & + & P. aeruginosa $99.9 \%$ \\
\hline P6 & P. aeruginosa & $99 \%$ & Granite before C/D & bacillus - & + & + & + & + & + & + & - & + & + & + & P. aeruginosa $99.9 \%$ \\
\hline P7 & ** & & Porcelain before $C / D$ & bacillus - & + & + & + & + & + & + & - & + & + & ++ & P. aeruginosa $99.9 \%$ \\
\hline P9 & ** & & Stainless steel before C/D & bacillus - & + & + & + & + & + & + & - & - & + & + & P. fluorescens $99.6 \%$ \\
\hline P11* & P. aeruginosa & $99 \%$ & Polypropylene after C/D & bacillus - & + & + & + & + & + & - & - & + & + & ++ & P. aeruginosa $98.5 \%$ \\
\hline P12 & ** & & Polypropylene after C/D & bacillus - & + & + & + & + & + & - & - & + & + & + & P. aeruginosa $97.8 \%$ \\
\hline P14 & P. aeruginosa & $99 \%$ & Polypropylene after C/D & bacillus - & + & - & + & + & + & - & - & + & + & - & P. aeruginosa $97.8 \%$ \\
\hline P15 & P. aeruginosa & $99 \%$ & Polypropylene before C/D & bacillus - & + & - & + & + & + & - & - & + & + & - & P. aeruginosa $97.8 \%$ \\
\hline P18 & $P$. aeruginosa & $99 \%$ & Polypropylene after C/D & bacillus - & + & - & + & + & + & - & - & + & + & ++ & P. aeruginosa $98.5 \%$ \\
\hline P20 & ** & & Polypropylene before C/D & bacillus - & + & - & + & - & - & - & - & - & + & - & P. aureofaciens $90 \%$ \\
\hline
\end{tabular}

$* *$, tests not made; $C / D$, cleaning and disinfection. 
Table 3. The various biochemical tests for the identification of Enterobacteriaceae spp. strains

\begin{tabular}{|c|c|c|c|c|c|c|c|c|c|c|c|c|c|c|}
\hline \multirow{3}{*}{$\begin{array}{l}\text { Code of } \\
\text { strains }\end{array}$} & \multicolumn{2}{|c|}{$\begin{array}{c}\text { Automated microbiology } \\
\text { instruments reference BD- } \\
\text { PHONIX }\end{array}$} & \multicolumn{12}{|c|}{ Biochemical tests } \\
\hline & \multirow[b]{2}{*}{ identification } & \multirow[b]{2}{*}{$\begin{array}{l}\text { Confidence } \\
\text { value }\end{array}$} & \multirow[b]{2}{*}{ Origin } & \multirow[b]{2}{*}{$\begin{array}{l}\text { Gram } \\
\text { stain }\end{array}$} & \multirow[b]{2}{*}{$\begin{array}{l}\text { Oxidase } \\
\text { test }\end{array}$} & \multirow[b]{2}{*}{$\begin{array}{l}\text { Catalase } \\
\text { tests }\end{array}$} & \multirow[b]{2}{*}{$\begin{array}{l}\text { Tests } \\
\text { mobility }\end{array}$} & \multicolumn{4}{|c|}{ IMVIC TEST } & \multicolumn{2}{|l|}{ Profile API 20E } & \multirow{2}{*}{$\begin{array}{c}\text { lactose } \\
\text { fermentation } \\
(+)(B C P)\end{array}$} \\
\hline & & & & & & & & Indole & $\begin{array}{l}\text { Methyl } \\
\text { red }\end{array}$ & $\begin{array}{l}\text { Vosges } \\
\text { Proskaner }\end{array}$ & Citrate & Identification & $\begin{array}{c}\% \\
\text { confidence }\end{array}$ & \\
\hline E3 & E. coli & $0 \%$ & porcelain before C/D & - & + & + & - & - & + & - & + & Enterobacter cloace & 99.1 & + \\
\hline E4 & & & stainless steel before C/D & - & + & + & - & - & + & - & + & enterobacter agglomerans & 58.5 & + \\
\hline E5 & & & stainless steel before C/D & - & + & + & - & - & + & - & - & Enterobacter cloace & 86.6 & - \\
\hline E6 & & & Polypropylene after C/D & - & + & + & - & - & + & - & + & Enterobacter agglomerans 1 & 43.0 & - \\
\hline E7 & $\begin{array}{l}\text { Citrobacter } \\
\text { Freundii }\end{array}$ & $99 \%$ & Polypropylene before C/D & - & + & - & - & - & + & - & - & Citrobacter freundii & 99.0 & + \\
\hline E8 & & & polypropylene after C/D & - & - & + & - & - & + & - & + & Enterobacter cloace & 86.6 & - \\
\hline E9 & & & polypropylene after C/D & - & + & + & - & - & + & - & + & Enterobacter cloace & 86.6 & - \\
\hline E10 & & & polypropylene before C/D & - & + & - & - & - & + & - & + & Enterobacter cloace & 86.6 & - \\
\hline E11 & & & granite after C/D & - & - & + & - & - & + & - & + & Tatumella ptyseos & 89.7 & - \\
\hline E14 & & & porcelain before $\mathrm{C} / \mathrm{D}$ & - & - & + & - & - & + & - & + & Chromobacterium.violaceum & 95.2 & - \\
\hline E15 & & & porcelain before C/D & - & - & + & - & - & + & - & + & chryseomonas luteola & 96.2 & - \\
\hline E18 & & & polypropylene after C/D & - & + & + & - & - & + & - & + & Enterobacter.annigenus 2 & 97.7 & - \\
\hline E19 & & & stainless steel before C/D & - & + & - & - & - & + & - & + & Enterobacter sakazakii & 97.9 & - \\
\hline E20 & & & stainless steel before C/D & - & + & + & - & - & + & - & + & Enterobacter cloace & 86.6 & - \\
\hline Witness, E.coli & & & & - & + & + & - & - & + & - & + & E. coli & 97.7 & \\
\hline
\end{tabular}

\footnotetext{
$*^{* *}$, tests not made; $C / D$, cleaning and disinfection.
}

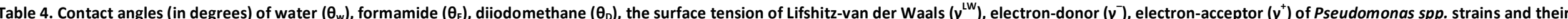
free energy of interaction with water $\left(\Delta \mathrm{G}_{\text {iwi }}\right)$

\begin{tabular}{|c|c|c|c|c|c|c|c|c|}
\hline \multicolumn{2}{|r|}{ Strains } & \multicolumn{3}{|c|}{ Contact angles } & \multicolumn{3}{|c|}{ Tension de surface (mJ $m-2)$} & \multirow[t]{2}{*}{$\Delta G_{i w i}\left(m j / m^{2}\right)$} \\
\hline & & $\vartheta$ diiométhane & Ө formamide & $\vartheta$ water & $\gamma^{\mathrm{TW}}$ & $\gamma^{+}$ & $v$ & \\
\hline P1 & P.stutzeri & $98.7(0.4)$ & $54.9(0.3)$ & $39.6(0.2)$ & $9.2(0.1)$ & $6.0(0.1)$ & $56.4(0.4)$ & 20.3 \\
\hline P3 & P. aeruginosa & $104.6(0.3)$ & $44.1(0.4)$ & $44.9(0.3)$ & $7.1(0.1)$ & $14.7(0.3)$ & $36.3(0.5)$ & -3.0 \\
\hline P4 & P. aureofaciens & 114.6(1.1) & $36.6(0.5)$ & $31.9(0.3)$ & $4.3(0.2)$ & $21.3(0.8)$ & $46.1(0.1)$ & -10.2 \\
\hline P5 & P.aeuruginosa & $131.8(0.3)$ & $31.8(0.2)$ & $35.4(0.2)$ & $1.4(0.1)$ & $34.6(0.2)$ & $37.4(0.2)$ & -27.6 \\
\hline P6 & P.aeuruginosa & $98.1(0.4)$ & $61.5(0.2)$ & $34.6(1.7)$ & $9.4(0.1)$ & $2.9(0.2)$ & $74.1(2.6)$ & 42.6 \\
\hline P7 & P.aeuruginosa & $91.5(0.6)$ & $46.0(1.0)$ & $39.3(0.1)$ & $12.0(0.3)$ & $7.6(0.7)$ & $47.5(1.4)$ & 14.2 \\
\hline P9 & P.fluorescens & $75.2(0.6)$ & $20.3(0.3)$ & $11.7(0.3)$ & $20(0.3)$ & $7.3(0.2)$ & $55(0.3)$ & 22.2 \\
\hline P11 & P. aeruginosa & $70.1(0.5)$ & $47.4(0.2)$ & $25.3(0.2)$ & $22.8(0.3)$ & $1.0(0.1)$ & $69.1(0.5)$ & 52.9 \\
\hline P12 & P.aeuruginosa & $114.8(0.0)$ & $36.0(0.1)$ & $25.0(0.2)$ & $4.3(0.0)$ & $20.6(0.1)$ & $53.2(0)$. & -8.7 \\
\hline P14 & P. aeruginosa & $112.5(0.1)$ & $51.6(0.2)$ & $42.7(0.5)$ & $4.8(0.0)$ & $13.4(0.2)$ & $46.2(0.7)$ & -2.3 \\
\hline P15 & P. aeruginosa & $111.5(0.2)$ & $85.8(1.8)$ & $41.8(0.4)$ & $5.1(0.1)$ & $0.1(0.1)$ & $105.4(4.4)$ & 86.3 \\
\hline $\mathrm{P} 18$ & P.aeuruginosa & $115.6(0.2)$ & $41.2(0.4)$ & $27.4(0.2)$ & $4.1(0.1)$ & $18.3(0.4)$ & $55.6(0.3)$ & -6.4 \\
\hline P20 & P.aureofaciens & $86.4(1.3)$ & $59.9(1.2)$ & $48.7(0.5)$ & $14.3(0.6)$ & $16.8(15.8)$ & $34.9(16.0)$ & 1.8 \\
\hline
\end{tabular}




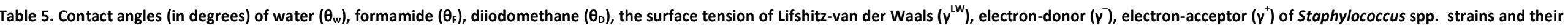
free energy of interaction with water $\left(\Delta G_{i w i}\right)$.

\begin{tabular}{|c|c|c|c|c|c|c|c|c|}
\hline & \multirow[t]{2}{*}{ Strains } & \multicolumn{3}{|c|}{ Contact angles } & \multicolumn{3}{|c|}{ Tension de surface ( $m J . m-2)$} & \multirow[t]{2}{*}{$\Delta G_{i w i}\left(m j / m^{2}\right)$} \\
\hline & & Ө diiométhane & $\vartheta$ formamide & $\vartheta$ water & $\gamma^{2 W}$ & $\gamma^{-}$ & $v$ & \\
\hline S1 & Staph.lentus & $96.4(0.5)$ & $44.5(0.4)$ & $40.9(0.3)$ & $10.0(0.2)$ & $10.1(0.4)$ & $42.9(0.7)$ & 6.88 \\
\hline S2 & Staph.xylosus & $70.8(0.1)$ & $38.5(0.3)$ & $31.5(0.2)$ & $22.5(0.1)$ & $3.2(0.1)$ & $51.7(0.5)$ & 27.91 \\
\hline s6 & Staph. xylosus & $80.6(0.1)$ & $58.4(0.2)$ & $41.7(0.2)$ & $17.2(0.1)$ & $1.1(0.0)$ & $59.2(0.6)$ & 41.71 \\
\hline s8 & Staph. aureus & $115.3(0.2)$ & $33.5(0.1)$ & $45.7(1.1)$ & $4.2(0.1)$ & $26.9(0.2)$ & $26.9(1.4)$ & -13.58 \\
\hline S9 & Staph. xylosus & $120.2(1.4)$ & $38.2(0.9)$ & $51.2(0.2)$ & $3.2(0.3)$ & $28.4(1.5)$ & $22.8(0.9)$ & -16.14 \\
\hline S10 & Staph.capitis & $95.0(0.2)$ & $36.5(0.8)$ & $32.7(0.4)$ & $10.6(0.1)$ & $11.9(0.5)$ & $46.5(1.2)$ & 7.42 \\
\hline S17 & Staph. xylosus & $114.0(0.4)$ & $36.6(0.6)$ & $28.2(0.4)$ & $4.5(0.1)$ & $20.3(0.2)$ & $50.5(0.6)$ & -8.33 \\
\hline S18 & Staph. xylosus & $129.8(0.2)$ & $36.6(0.3)$ & $42.6(0.2)$ & $2(0.0)$ & $32(0.1)$ & $32(0.3)$ & -24.1 \\
\hline S19 & Staph.sciuri & $58.8(0.4)$ & $37.0(0.2)$ & $31.2(0.7)$ & $29.2(0.2)$ & $1.5(0.1)$ & $51.4(1.0)$ & 31.4 \\
\hline S20 & Staph. xylosus & $88.0(2.6)$ & $46.3(0.3)$ & $36.1(0.2)$ & $13.7(1.2)$ & $5.8(0.8)$ & $52.1(0.4)$ & 21.1 \\
\hline
\end{tabular}

Standard deviation was given in parentheses.

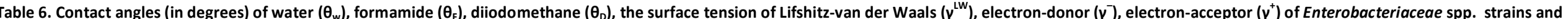
their free energy of interaction with water $\left(\Delta \mathrm{G}_{\mathrm{iwi}}\right)$.

\begin{tabular}{|c|c|c|c|c|c|c|c|c|}
\hline \multicolumn{2}{|r|}{ Strains } & \multicolumn{3}{|c|}{ Contact angles } & \multicolumn{3}{|c|}{ Tension de surface $(\mathrm{mJ} . \mathrm{m}-2)$} & \multirow[t]{2}{*}{$\Delta G_{i w i}\left(m j / m^{2}\right)$} \\
\hline & & $\vartheta$ diiométhane & ध formamide & $\vartheta$ water & $\gamma^{2 \omega-}$ & $\gamma^{+-1}$ & $v$ & \\
\hline E3 & Enterobacter cloace & $97.0(0.4)$ & 1.1 & $27.1(0.4)$ & $9.8(0.2)$ & $17.1(0.1)$ & $43.6(0.2)$ & 1.1 \\
\hline E4 & Ent.agglomerans & $101.3(0.5)$ & -3.4 & $21.0(0.4)$ & $8.2(0.2)$ & $21.1(0.3)$ & $44.8(0.4)$ & -3.4 \\
\hline E5 & Enterobacter cloace & $100.8(0.4)$ & -0.8 & $17.2(0.4)$ & $8.4(0.2)$ & $19.1(0.3)$ & $49.6(0.2)$ & -0.8 \\
\hline E6 & Ent.agglomeranns 1 & $101.0(0.4)$ & -0.8 & $20.4(0.3)$ & $8.3(0.1)$ & $15.4(0.2)$ & $54.3(0.5)$ & -0.8 \\
\hline E7 & Citrobacter freundii & $100.5(0.6)$ & 12.3 & $26.0(0.6)$ & $8.5(0.2)$ & $10.9(0.2)$ & $59.1(0.9)$ & 12.3 \\
\hline E8 & Enterobacter cloace & $59.7(1.6)$ & 23.7 & $30.2(0.5)$ & $28.80 .9)$ & $2.7(0.5)$ & $47.1(1.3)$ & 23.7 \\
\hline E9 & Enterobacter cloace & $99.9(0.3)$ & 3.3 & $25.9(0.5)$ & $8.7(0.1)$ & $15.3(0.1)$ & $49.7(0.6)$ & 3.3 \\
\hline E10 & Enterobacter cloace & $100.1(0.3)$ & -3.1 & $29.6(0.2)$ & $8.7(0.1)$ & $20.1(0.2)$ & $39.4(0.2)$ & -3.1 \\
\hline E11 & Tatumella ptyseos & $106.5(0.2)$ & 9.8 & $25.1(0.4)$ & $6.5(0.1)$ & $11.8(0.1)$ & $63.1(0.4)$ & 9.8 \\
\hline E14 & Chnomo.violceum & $90.6(0.2)$ & 17.7 & $32.5(1.0)$ & $12.5(0.1)$ & $7.8(0.0)$ & $52.3(0.7)$ & 17.7 \\
\hline E15 & Chryseomonas luteola & $90.8(0.3)$ & 6.2 & $44.7(0.4)$ & $12.3(0.1)$ & $8.8(0.1)$ & $37.3(0.4)$ & 6.2 \\
\hline E18 & Enterobacter.annigenus 2 & $101.4(0.8)$ & 3.9 & $42.3(1.5)$ & $8.2(0.2)$ & $11.2(0.2)$ & $42.9(1.8)$ & 3.9 \\
\hline E19 & Enterobacter sakazakii & $90.3(0.1)$ & 4.8 & $33.7(0.2)$ & $12.6(0.1)$ & $8.9(0.1)$ & $35.0(13.2)$ & 4.8 \\
\hline E20 & Enterobacter cloace & $92.2(0.3)$ & 22.5 & $35.8(0.4)$ & $11.7(0.2)$ & $5.8(0.1)$ & $55.7(0.4)$ & 22.5 \\
\hline
\end{tabular}


